\title{
Peculiarities of online banking in the framework of ensuring sustainable development of the economy
}

\author{
Farkhod Mukhamedov ${ }^{1}$, Maksim Maramygin ${ }^{2}$, Natalya Mokeeva ${ }^{2, *}$, and Valeria \\ Rodicheva $^{2}$ \\ ${ }^{1}$ Tashkent Financial Institute, Amira Timura Avenue, 60 A, Tashkent, Uzbekistan \\ ${ }^{2}$ Ural State University of Economics, 8 Marta Str., 62, 620144 Ekaterinburg, Russia
}

\begin{abstract}
Abstract. The development of online banking in the economies of many countries, including Russia, is a fairly young direction and now continues its active growth, and the formation of banking ecosystems is at the stage of origin and initial formation into an independent unit. However, many banks treat remote customer service not as a possible way of development, but as a forced measure. Implementation of new technologies in the banking sector is a little slower than in other segments of the industry. This is primarily due to the very conservative views of the top managers of the bank, as well as of many consumers of banking services. When investigating possible problems and prospects of development of online banks, it is possible to form a pool of new opportunities for growth of the banking system and development of the product line of individual banks.
\end{abstract}

\section{Introduction}

Year after year, modern technologies are changing settlement systems, bringing more and more new to the daily needs of payments of various types. At the same time, regardless of the company's or sphere's affiliation, financial market participants try to implement modern technologies thus not only allowing clients to receive the service remotely, but also saving the company itself on expenses. Technological development is mostly needed not so much by customers as by banks themselves, to optimize internal processes. That's why there appeared such concepts as neo-bank, online bank, virtual bank and Direct Bank.

In order to continue studying this topic in the future it is necessary to determine the difference of these interpretations. It should be noted that often banks without offices are called "Direct Bank" direct bank, so the name is fully consistent with the bank's ideology and position in history.

The direct bank is a bank without a branch network, which offers its services remotely through Internet banking and telephone banking, and can also provide access through ATMs (often through interbank network alliances), mail and cell phone[1]. By eliminating the costs associated with bank branches, direct banks can make significant savings that they

\footnotetext{
* Corresponding author: natmokeeva@yandex.ru
} 
can direct to customers through higher interest rates or lower service charges. Accordingly, the term "DirectBank" is used only to describe foreign banks, as this term, according to the authors, is correct from the historical point of view.

Neobank - a bank with a small number of offline branches, carrying out all interaction with the client through remote channels such as application, sms-informing, call-centers, etc. To characterize such banks, let us highlight their distinctive features [1]:

- availability of an application for the bank's target audience (for individuals or legal entities) and their continuous updating;

- the main channel of interaction with the client - call-center or application;

- $\quad$ courier system for card products delivery and contract conclusion;

- $\quad$ lack of a large branch network;

- $\quad$ the bank has a large staff of developers and other IT-specialists;

- $\quad$ special offers separately for legal entities and individuals;

- 24-hour technical support;

- $\quad$ availability of a marketing department or division that analyses customer needs and actively uses new advertising channels;

- $\quad$ use of mobile payment systems (GooglePay, ApplePay, SamsungPay).

Virtual bank (digital bank) - a financial service that meets all of the above requirements for neo-banks, but does not have its own license to operate. Examples of such banks are: Rocketbank, Sphere, Tochka, DeloBank.

Online bank - a bank that fully complies with the list of distinctive features of a neobank, but does not have branches. An example of such banks is TinkoffBank.

\section{Materials and methods of e-banking}

As it was mentioned earlier for "Direct Bank", continuous technological development and improvement of channels for interaction with clients (e-banking) are important conditions for existence and prosperity. Accordingly, remote banking (RBS) becomes the basic concept that characterizes such banks.

RBS - a set of technologies that allows financial and credit organizations to provide their services to end users remotely through telecommunications, i.e. without the direct visit to the office by the latter [2]. At present, several most common classification criteria for ebanking services can be identified (Table 1).

Table 1. Classification of RBS

\begin{tabular}{|l|l|l|}
\hline $\begin{array}{c}\text { Character of } \\
\text { classification }\end{array}$ & \multicolumn{1}{|c|}{ Type of RBS } & \multicolumn{1}{c|}{ Characteristics } \\
\hline $\begin{array}{l}\text { Type of } \\
\text { communication } \\
\text { channels }\end{array}$ & $\begin{array}{l}\text { PC-Banking } \\
\text { ("client-bank") }\end{array}$ & $\begin{array}{l}\text { Direct communication with the bank via modem with } \\
\text { installation of special software on the client's } \\
\text { computer }\end{array}$ \\
\cline { 2 - 3 } & $\begin{array}{l}\text { Telebank } \\
\text { system (phone- } \\
\text { banking) }\end{array}$ & $\begin{array}{l}\text { Payment and information banking services by phone / } \\
\text { fax using computer telephony }\end{array}$ \\
\cline { 2 - 3 } & Internet banking & $\begin{array}{l}\text { There is no need to have special software and one can } \\
\text { work with the bank account from any computer } \\
\text { connected to the Internet. }\end{array}$ \\
\cline { 2 - 4 } & $\begin{array}{l}\text { Servicing via } \\
\text { ATM-banking }\end{array}$ & $\begin{array}{l}\text { ATMs are divided into categories by: Cash-Out, } \\
\text { Cash-In, Cash-recycling and differ in the set of } \\
\text { functions performed. }\end{array}$ \\
\cline { 2 - 4 } & APP - banking & \begin{tabular}{l} 
Working through a mobile bank application \\
\hline
\end{tabular}
\end{tabular}


Continuation of Table 1.

\begin{tabular}{|l|l|l|} 
Type of service & Informational & $\begin{array}{l}\text { Provision of financial information to users, e.g. } \\
\text { receipt of a statement, data on the latest transactions, } \\
\text { SMS message on transactions, bank news, exchange } \\
\text { rates, precious metals and securities quotes, etc. }\end{array}$ \\
\cline { 2 - 3 } & Transactional & Carrying out operations by the client \\
\cline { 2 - 3 } & Consulting & $\begin{array}{l}\text { Receiving a consultation without visiting the bank } \\
\text { office with the possibility of client identification }\end{array}$ \\
\hline \multirow{2}{*}{$\begin{array}{l}\text { Subject of } \\
\text { service }\end{array}$} & $\begin{array}{l}\text { Corporate } \\
\text { clients }\end{array}$ & $\begin{array}{l}\text { Remote provision of services and products to } \\
\text { corporate clients }\end{array}$ \\
\cline { 2 - 4 } & Private clients & $\begin{array}{l}\text { Remote provision of services and products to } \\
\text { individual customers }\end{array}$ \\
\hline
\end{tabular}

The most important principle of e-banking is the remote exchange of information between the client and the bank. On the part of the bank the required level of security and confidentiality of this exchange is provided, as now the client of the bank is able to both receive information on their accounts and products, and manage them, making all kinds of financial transactions. The client's capabilities may include remote access to accounts, transfers, payment for services, opening deposits, and credit processing. In order to get an access to the remote access, the client only needs to have one of the communication channels, such as telephone or Internet and computer or telephone.

That is why remote banking is sometimes referred to as electronic banking, allocating such types of channels for the provision of services as via the Internet, mobile, telephone, through special terminals and ATMs. As there is still no generally accepted definition of remote banking, there is no specific classification by type and form.

\section{Results and Discussion}

The notion of direct bank became widely known with the emergence of online banking technology in the early 1990s, which led to the creation of a number of online banks, although many of them were owned by traditional banks (Table 2).

Table 2 Appearance of direct banks [3]

\begin{tabular}{|l|l|}
\hline $\begin{array}{c}\text { The year of } \\
\text { appearance }\end{array}$ & \multicolumn{1}{c|}{ Bank } \\
\hline 1989 & "First Direct", Great Britain \\
\hline 1995 & Security First Network Bank (SFNB), USA \\
\hline 1998 & Eggbank, USA \\
\hline 1999 & $\begin{array}{l}\text { ENBA, Ireland, Internet incubator of the company under the } \\
\text { bank license of French bank, Banque d'Escompte }\end{array}$ \\
\hline 2000 & $\begin{array}{l}\text { Bank of Asia finatiQ, they were a division of Oversea- } \\
\text { Chinese Banking Corporation (OCBC) from Singapore }\end{array}$ \\
\hline
\end{tabular}

Some direct banks initially offered only online account maintenance, opening and maintenance of deposits. These banks did not have a traditional banking infrastructure, they did not have a network of branches, due to the savings that allowed many of them to offer savings accounts with higher interest rates and loans with lower interest rates than most traditional banks. "Direct Bank" positioned itself as the first to refuse from the branches. The contact with clients was made with the help of call-centers, which worked 24 hours a day, which allowed solving problems here and now, rather than waiting for your turn in the 
office. Virtual banks can operate from almost one computer and an administration server without a significant infrastructure. However, the original consumer did not hesitate to conduct money transactions over the Internet, especially with education, they could not cope face to face. Over time, the concept of "Virtual Bank" was introduced, which began to displace the original definition of "Direct Bank".

At the moment 7 most significant direct banks should be distinguished [3]:

- "Ally Bank", part of Ally Financial;

- "Bank of Internet USA", part of "BofI Federal Bank";

- "Smile", part of "The Co-operative Bank";

- "First Direct", part of "HSBC";

- "ING Direct", part of "ING Group";

- "Tinkoff Bank";

- “Telenorbank", part of "Telenor Group".

This list demonstrates that each direct bank belongs to or is a part of another larger bank, against this background "Tinkoff Bank" is stood out, which is a completely independent unit.

All of the above banks provide services remotely and are constantly developing their communication channels, which allow them to keep up with trends and thus meet the requirements of modern society. The main trendsetters in working with clients are "First Direct" and "UBank". They were able to present their products to potential customers in an original way, which allowed them to operate a huge base.

In Russia, there is only one full-fledged direct bank that competes with the classical ones, the rest is virtual banks, the so-called services such as Rocketbank, Touchbank, which will not be able to claim the same extensive audience due to its narrow focus and limited services. But they in their turn help to develop and not to stand still at Tinkoff Bank. Moreover, the latter has gained huge popularity among consumers of the Russian market, which will allow to develop at the same pace in the future.

As you can see from the above, the whole history of online banking development in the Russian market is closely linked to the development of Tinkoff Bank, i.e. the development of Direct Bank in Russia. Of course, in 2013 so-called virtual banks such as InstaBank and Rocketbank started to appear, but their work in the banking sector is traditionally limited.

Only with the maximum attention to the disadvantages and the realization of the benefits one can say that the bank has created an interesting and high-quality banking product, which can be attributed to neo-banking, online banking or virtual banks.

The creation of such a solution for a bank or its own modification to this type of banks can reduce costs in many areas and redistribute free cash in the development of its own technologies, products, their promotion and advertising.

Thus, for example, the structure of employees at banks is strikingly different, as can be seen from Table 3.

Table 3. Main HR characteristics of banks, to branches and cities of presence, 2019[4]

\begin{tabular}{|l|c|c|c|}
\hline \multicolumn{1}{|c|}{ Index } & Tinkoff Bank & Alfa-bank & Sovcombank \\
\hline Number of branches and offices, pcs. & 1 & 800 & 2500 \\
\hline Number of employees, person & 20000 & 27359 & 15000 \\
\hline Cities of service, pcs. & 1086 & 250 & 925 \\
\hline Employee expenses, billion rubles & 24,85 & 43,81 & 22,93 \\
\hline $\begin{array}{l}\text { Expenses per employee, million rubles per } \\
\text { year }\end{array}$ & 1,24 & 1,60 & 1,52 \\
\hline
\end{tabular}

As can be seen from Table 3, Tinkoff Bank has the smallest number of offices, but at the same time, such a result was achieved primarily due to the developed delivery system, which is due to the strategy of the bank without branches. Due to the fact that the bank 
mainly uses specialists of call-centers and representatives of the bank (suppliers) in different regions of the country, it is possible to reduce expenses for one employee. This approach can be called effective, because the bank has practically no restrictions on the territory of its presence. Alfa-Bank's largest expenses are primarily due to the fact that its offices are present mainly in large cities where income levels are higher.

The main and important feature of online banks is their structure of operating costs, they spend money on other areas and have more room for maneuver when working with clients, unlike classical banks. In today's Russian reality, the development of online banking was inevitable, as well as taking into account the legislation and its ongoing reform, there are increasing opportunities to work with clients remotely. If we also take into account the current global situation and the pandemic, it is the remote interaction approach that has the greatest chances of successful development and minimal losses during the crisis.

Bank clients evaluate the mobile application interface, security and a set of services as part of the transition to RBS. Consulting agency Markswebb annually presents ratings related to mobile applications for individuals and legal entities. The Company uses its own methodology to evaluate bank applications and then publishes the results with comments, as in 2019 the rating of applications for individuals was as follows (Table 4).

Table 4. Rating of mobile banks for daily tasks [5]

\begin{tabular}{|l|c|c|c|c|}
\hline \multirow{2}{*}{\multicolumn{1}{|c|}{ Bank }} & \multicolumn{2}{c|}{ Android } & \multicolumn{2}{c|}{ iOS } \\
\cline { 2 - 5 } & Rating & Place & Rating & Place \\
\hline Tinkoff Bank & 78,7 & 1 & 80,1 & 1 \\
\hline Ak Bars Bank & 76,1 & 2 & 76,6 & 2 \\
\hline Alfa- Bank & 71,1 & 3 & 72,5 & 3 \\
\hline Post Bank & 69,1 & 6 & 69,6 & 4 \\
\hline Bank Levoberezhny & 69,5 & 5 & 69,1 & $5-6$ \\
\hline RosBank & 69,0 & $7-8$ & 69,1 & $5-6$ \\
\hline BCS Bank & 70,0 & 4 & 68,5 & 7 \\
\hline Russian Standard Bank & 69,0 & $7-8$ & 67,5 & 8 \\
\hline VTB & 66,1 & 9 & 66,7 & 9 \\
\hline MCB & 63,7 & 14 & 65,7 & 11 \\
\hline Raiffeisenbank & 65,0 & $11-12$ & 65,5 & 12 \\
\hline Bank Zenit & 64,1 & 13 & 63,0 & 13 \\
\hline Bank of Kazan & 63,5 & 15 & 62,5 & 14 \\
\hline Bank Otkritie & 62,1 & 16 & 62,1 & 15 \\
\hline Sberbank & 59,5 & 19 & 60,6 & $18-19$ \\
\hline RocketBank & 59,9 & 18 & 59,3 & 20 \\
\hline
\end{tabular}

This rating shows how fully the mobile bank corresponds to the model of "ideal application", where the user in a daily mode can make various typical payments and transactions, as well as easily and conveniently manage their own funds in the bank account [1]. Thanks to such a decision everyone will be able to pay these bills on time and without unnecessary actions and trips, which will allow not to worry about receiving a penalty for late payment. Another important aspect is tying the cards of other banks, because most people still have to receive their wages not on the main card, so it is important for them to transfer money from one card to another twice a month. The majority of bank applications are already able to save such information, so that they do not have to enter details all the time, but unfortunately not all of them [6]. Also, taking into account the constant staying at home and the increasing number of payments through various sites, an important aspect is the possibility of setting limits on the cards, because as the number of purchases on the Internet increases the chance to lose money by entering the card number on an inappropriate or unreliable site. By setting limits, you can minimize risks and block 
unwanted operations. Through the development of these given aspects, banks will be able to provide more and more useful functions to their customers.

But of course, online banking activity is connected with assessment of a number of advantages and disadvantages, which can be singled out separately for banks and clients (Table 5).

Table 5. Advantages and disadvantages of online-banking [7-9]

\begin{tabular}{|c|c|}
\hline Advantages & Disadvantages \\
\hline \multicolumn{2}{|c|}{ For banks: } \\
\hline $\begin{array}{l}\text { - constant technological } \\
\text { development of banks; } \\
-\quad \text { permanent development of } \\
\text { relations between banks for interaction } \\
\text { and provision of services; } \\
-\quad \text { "healthy" competition; } \\
\text { - interaction with technology } \\
\text { companies and structures. }\end{array}$ & $\begin{array}{l}\text { - channel of an access to confidential } \\
\text { information of the bank's client, which can lead } \\
\text { to huge losses, both informational and } \\
\text { financial, in the absence of due attention to } \\
\text { security and encryption; } \\
\text { - many non-banking structures that entice } \\
\text { clients away; } \\
\text { - a constant search for new solutions to } \\
\text { attract even more customers, i.e. to be one step } \\
\text { ahead of ordinary banks. }\end{array}$ \\
\hline \multicolumn{2}{|c|}{ For clients: } \\
\hline $\begin{array}{l}\text { - customer time optimization: } \\
\text { consultation in the bank's application } \\
\text { chat room or call-center; } \\
-\quad \text { all the necessary information in } \\
\text { the application; } \\
-\quad \text { constant technological } \\
\text { development; } \\
\text { - withdrawal of funds is possible } \\
\text { in almost any ATM, so there is no need } \\
\text { to look for "your" ATM. This is due to } \\
\text { the fact that "Directbank" is a member } \\
\text { of banking alliances, thus allowing its } \\
\text { customers to use ATMs of competitors; } \\
\text { - full control of your account. }\end{array}$ & $\begin{array}{l}\text { - constant use of mobile connections or } \\
\text { the Internet, accordingly, in their absence it } \\
\text { will not be possible to use the necessary } \\
\text { services or solve the problem; } \\
\text { - Absence of something substantial, } \\
\text { which may give rise to doubt in a person about } \\
\text { such banks; } \\
\text { - various commissions, which are } \\
\text { connected with the absence of own offices, } \\
\text { ATMs, because the possibility to deposit or } \\
\text { withdraw funds from the account with the help } \\
\text { of third parties is free for the bank; } \\
\text { - rejection by some organizations of } \\
\text { innovative solutions that are used by online } \\
\text { banks. }\end{array}$ \\
\hline
\end{tabular}

\section{Conclusion}

In today's world, online banks have gained huge popularity, almost in every economically developed country there is an online bank that competes with banks of the classical structure. But if we look at one feature, the direct banks are controlled by a large, even systemic for each country of the bank, although they started their existence separately. This shows that banks believe in the success of remote interaction and service. In Russia a similar situation has been formed in a similar way.

As time shows in Russia, such technologies and the approach get accustomed much faster, because foreign banks were reluctant to use new technologies and approaches because they were not ready to replace all current equipment, to hire more staff of developers and to retrain their own users who were used to the old approaches [10]. It is also due to the fact that in Russia, entrepreneurship began to emerge much later, and the use of card payment technology through terminals came some time later than it appeared in other countries. Now the development of retail business, which contributes to the introduction of new technologies and solutions is on such a path that, for example, NFC payment terminals in Russia are almost everywhere in large cities, because all this has been 
installed and bought recently, and in Europe or the U.S. terminals are used for a long time, and entrepreneurs and banks are in no hurry to change them to newer ones that support contactless payment. This is just one example that shows the current state of affairs in the implementation of banking technologies. Therefore, a large number of services and new banking brands related to the provision of services through remote channels began to appear in Russia [11]. Reasons that online banks use as advantages and attract new customers:

- customers, especially entrepreneurs, value their time, which means that remote services and banking services will allow them not to spend this precious resource on trips to the office;

- the population began to use smartphones to solve everyday tasks, which are financial services, which means that banks will be able to be in constant contact with the client while creating the application and its development;

- the constant contact with the client via chat or phone will allow you to solve problems as quickly as possible.

\section{References}

1. V.A. Pankov, N.N. Mokeeva, Spring Science Days Hsem, 2019

2. A. M. Gerasimovich, Analysis of remote customer service in banking, 2015

3. Analytical resource "Moneysavingexpert", http://www.moneysavingexpert.com/

4. Analytical resource "Banks.ru", http://www.banki.ru/

5. Mobile Bank Rank 2019 by MarksWebb, https://markswebb.ru/

6. L. Yuzvovich, E.A. Trofimova, Improving the assessment of the effectiveness of a commercial bank in the context of interbank competition: monograph, 2018.

7. M.S. Maramygin, L.I. Yuzvovich, E.V. Strelnikov. Atlantis Press, 36 (2019)

8. L. Nugroho, A.Badawi, N. Hidayah, Int. J. of Financial research, 108 (2019)

9. O. Kryvtsov, L. Petersen, J. of monetary economics (2020)

10. E. Jones, A. Zeitz., International studies, 908 (2019)

11. E. Campiglio, Y. Dafermos, P. Monin., Nature climate change, 8 (2018) 